\title{
Use of low-value pediatric services in the Military Health System
}

Tracey Pérez Koehlmoos ${ }^{1}$, Cathaleen Madsen ${ }^{1,2^{*}}$ D, Amanda Banaag ${ }^{1,2}$, Qiong Li ${ }^{1,2}$, Andrew J. Schoenfeld ${ }^{3}$ and Joel S. Weissman ${ }^{3}$

\begin{abstract}
Background: Low-value care (LVC) is understudied in pediatric populations and in the Military Health System (MHS). This cross-sectional study applies previously developed measures of pediatric LVC diagnostic tests, procedures, and treatments to children receiving care within the direct and purchased care environments of the MHS.

Methods: We queried the MHS Data Repository (MDR) to identify children $(n=1,111,534)$ who received one or more of 20 previously described types of LVC in fiscal year 2015. We calculated the proportion of eligible children and all children who received the service at least once during fiscal year 2015. Among children eligible for each measure, we used logistic regressions to calculate the adjusted odds ratios (AOR) for receiving LVC at least once during fiscal year 2015 in direct versus purchased care.
\end{abstract}

Results: All 20 measures of pediatric LVC were found in the MDR. Of the 1,111,534 eligible children identified, $15.41 \%$ received at least one LVC service, and the two most common procedures were cough and cold medications in children under 6 years and acid blockers for infants with uncomplicated gastroesophageal reflux. Eighteen of the 20 measures of pediatric LVC were eligible for comparison across care environments: 6 were significantly more likely to be delivered in direct care and 10 were significantly more likely to be delivered in purchased care. The greatest differences between direct and purchased care were seen in respiratory syncytial virus testing in children with bronchiolitis $(A O R=21.01,95 \% \mathrm{Cl}=12.23-36.10)$ and blood tests in children with simple febrile seizure $(A O R=24.44,95 \% \mathrm{Cl}=5.49-108.82)$. A notably greater difference of inappropriate antibiotic prescribing was seen in purchased versus direct care.

Conclusions: Significant differences existed between provision of LVC services in direct and purchased care, unlike previous studies showing little difference between publicly and privately insured children. In fiscal year 2015, 1 in 7 children received one of 20 types of LVC. These proportions are higher than prior estimates from privately and publicly insured children, suggesting the particular need to focus on decreasing wasteful care in the MHS. Collectively, these studies demonstrate the high prevalence of LVC in children and the necessity of reducing potentially harmful care in this vulnerable population.

Keywords: Pediatrics, Low-value care, Child health, Military health system, Big data, TRICARE

\footnotetext{
*Correspondence: Cathaleen.madsen.ctr@usuhs.edu

${ }^{1}$ Uniformed Services University of the Health Sciences, 4301 Jones Bridge

Road, Bethesda, MD 20814, USA

${ }^{2}$ Henry M. Jackson Foundation for the Advancement of Military Medicine,

6720A Rockledge Drive, Bethesda, MD 20817, USA

Full list of author information is available at the end of the article
}

(c) The Author(s). 2020 Open Access This article is licensed under a Creative Commons Attribution 4.0 International License, which permits use, sharing, adaptation, distribution and reproduction in any medium or format, as long as you give appropriate credit to the original author(s) and the source, provide a link to the Creative Commons licence, and indicate if changes were made. The images or other third party material in this article are included in the article's Creative Commons licence, unless indicated otherwise in a credit line to the material. If material is not included in the article's Creative Commons licence and your intended use is not permitted by statutory regulation or exceeds the permitted use, you will need to obtain permission directly from the copyright holder. To view a copy of this licence, visit http://creativecommons.org/licenses/by/4.0/ The Creative Commons Public Domain Dedication waiver (http://creativecommons.org/publicdomain/zero/1.0/) applies to the data made available in this article, unless otherwise stated in a credit line to the data. 


\section{Background}

Healthcare costs in the United States have steadily increased over the last 20 years [1], reaching an estimated $\$ 2.9$ trillion in spending in 2014 [2]. While this accounts for nearly $\$ 10,000$ per person per year in 2017 [3], this expenditure does not necessarily translate into better health outcomes. Between 10 and $14 \%$ of all-payer healthcare spending represents inefficiencies in care delivery and overtreatment [4]. At best, these interventions provide no benefit to the patient, and at worst, they potentiate harm. Such care is broadly defined as "low-value care (LVC) or overuse" [5, 6]. Efforts such as Choosing Wisely [7], launched in 2012, have attempted to raise awareness regarding LVC across 500 physician-identified procedures that provide little to no patient benefit. However, these efforts do not provide a means of measuring low value care in a system.

Based on these lists, researchers have developed tools for examining LVC in large-scale claims data. For example, Schwartz et al. (2014) found that 25 to $42 \%$ of elderly Medicare beneficiaries received at least 1 of 26 lowvalue services in 2009 , resulting in $\$ 1.9$ billion to $\$ 8.5$ billion in expenditures [8]. Segal, et al. (2014) produced a list of 20 "indicator procedures" representative of broader overuse within a large healthcare system [9]. This list was later applied to the Military Health System (MHS) by Koehlmoos, et al. (2019), who demonstrated the existence of LVC for the first time in the MHS among the adult beneficiaries [10]. Similarly, Chua et al. (2016) developed a novel set of 20 claim-based measures for measuring overuse in the pediatric population [11]. The study found that at least 1 in 10 commercially insured US children received one or more low-value pediatric services during 2014, resulting in $\$ 27.0$ million in unnecessary spending, of which $\$ 9.2$ million was paid out-of-pocket (33.9\%).

The MHS provides care through a bifurcated system in which beneficiaries may receive Direct Care (DC) from providers at military treatment facilities (MTFs) including hospitals, major medical centers, and clinics, in the US and overseas; or Purchased Care (PC) through regional, non-exclusive civilian providers who accept the TRICARE insurance benefit. Building on the previous work, this study aimed to determine the degree of overuse for 20 previously published measures within the pediatric population of the MHS, as well as compare DC and PC systems for use of LVC. Results are expected to inform discussion of current plans to restructure the MHS, particularly the proposed shift of care for non-active duty beneficiaries including children to the civilian purchased care sector [12].

\section{Methods}

\section{Data source and study design}

We conducted a cross-sectional analysis of the 2015 Military Health System Data Repository (MDR) claims database. The MDR captures both encounter and claims data of care delivered at Military Treatment Facilities (MTFs/direct care) and at civilian fee-for-service facilities (purchased care) covered by TRICARE. TRICARE is the MHS insurance product, which provides universal coverage to approximately 9.4 million members. TRIC ARE beneficiaries include $20 \%$ active-duty military personnel and $80 \%$ retirees or family members, and are likely representative of the U.S. population under age 65 [13-16]. TRICARE does not include care delivered in combat zones, or through Veterans Affairs (VA) hospitals which are part of a separately administered system. TRICARE data have previously been employed in several studies designed to evaluate the quality of healthcare delivery in a variety of clinical contexts including surgical care, women's health and pediatrics [17-19].

\section{Study population}

Utilizing the Defense Enrollment Eligibility Reporting System (DEERS), this study identified 1,111,534 children and adolescents aged 0 to 18 years old, who were dependents of active duty and retired service members, and dependent survivors; and enrolled in TRICARE Prime benefits for the full 2015 fiscal year. As the MHS follows the Federal fiscal year calendar, the selection of dates for analysis includes October 1, 2014-September 30, 2015, and does not include the ICD-10-CM transition in October 2015. Selecting children who were dependents of active duty and retired service members, and dependent survivors ensured the study population would consistently utilize the MHS, and also eliminated the possibility of the older population (those aged 17 and 18) having enlisted status as either active duty or reservists and $\mathrm{Na}$ tional Guard service members.

\section{Construction of low-value service measures}

We adopted all 20 LVC measures in pediatric services developed by Chua et al. (2016) and which are reported here exactly as previously described [11]. No license was required in order to use this tool. Eleven of these measures were tests (6 diagnostic and 5 imaging), and the remainder were pharmaceuticals [11, 20]. Pharmaceutical codes for this study were adapted from the Market Scan therapeutic codes as used by Chua et al., and assessed in the MDR according to their American Hospital Formulary Service (AHFS) identification, as shown in Additional file 1 . Because many measures reported by Chua, et al. (2016) excluded children with specific diagnosis or procedure codes in previous claims, we used the fiscal year 2014 MDR records as a "look-back period" for the identification of LVC measures in fiscal year 2015. Due to the unavailability of exact birth date in the datasets, this study was not able to exclude infants aged $<90$ days or neonates aged $<=28$ days, and reduced the exclusion 
criteria to include all infants aged 0 years. This will only influence Measure 3, Testing for Respiratory Syncytial Virus (RSV) in Children with Bronchiolitis, and Measure 8, Ultrasound in Children with Cryptorchidism. We used the narrow, more specific versions of the measures developed by Chua et al. (2016) [11].

\section{Statistical analyses}

We calculated the proportion of children eligible for the measure who received the service at least once during fiscal year 2015, the number of services received per 100 eligible children, the proportion of children in the overall sample who received the service at least once during fiscal year 2015, and the proportion of children in the overall sample who received at least 1 of the 20 low value services during fiscal year 2015. In order to compare LVC measures in direct care vs. purchased care, patients were identified by the following criteria: 1) patients were assigned to direct or purchased care based on whether their primary care manager was in direct or purchased care, 2) those without a primary care manager were excluded, and 3) those who received any care in both direct and purchased care during fiscal year 2015 were excluded. Among children eligible for each measure, logistic regressions, adjusted by age and gender, were performed to compare the likelihood LVC in direct vs. purchased care. Due to the measure constructs and pharmacy data elements, we were unable to make comparisons in two measures (12: Cough and cold medications in children under 6 years, and 20: Acid blockers for infants with uncomplicated gastroesophageal reflux). All analyses were performed using SAS version 9.4 (SAS Institute, Inc., Cary, NC). The work was found exempt by the Institutional Review Board of the Uniformed Services University of the Health Sciences.

\section{Results}

\section{Overuse procedures}

Our study identified 1,111,534 eligible children (Table 1). Slightly more than $50 \%$ were male and $49 \%$ were female. The children were almost evenly split between the three age categories $(0-5$ year, $6-12$ years, and $13-18$ years) at $32.7,37$, and $30.3 \%$ respectively. In terms of primary care network, $68 \%$ of children were registered to the Direct Care setting and $31.5 \%$ were registered to receive care at civilian clinics and facilities in the Purchased Care setting.

All 20 measures of low value care were found in the MDR (Table 2). As seen in Table 2, the number of children receiving each test, procedure, or treatment varied from 39 for neuroimaging in simple febrile seizures, to 108,574 for cough and cold medications in children under 6 years. Per 100 children in denominator, the lowest rate of use was sinus imaging for children with acute
Table 1 Study Population Demographics, $n=1,111,534$

\begin{tabular}{ll}
\hline Gender & Count (\%) \\
Male & \\
Female & $567,086(51.0)$ \\
Age Group & $544,448(49.0)$ \\
$0-5$ & \\
6-12 & $363,376(32.7)$ \\
13-18 & $411,263(37.0)$ \\
Primary Care Manager's Network & $336,895(30.3)$ \\
Direct Care & \\
Purchased Care & $755,741(68.0)$ \\
None & $350,625(31.5)$ \\
\hline
\end{tabular}

sinusitis (0.19) and the greatest rate of use was oral antibiotics for acute otitis media with effusion (41.32). Overall, $15.41 \%$ of children in our study population received at least one indicator of low-value care by the narrow measure constructs, and a total of 1,106,366 children from our study population were the eligible for the comparison analysis of direct $(n=755,741)$ vs. purchased care $(n=350,625)$.

This study also compared results from DC vs PC (Table 3). Six services were significantly more likely in direct care, with the greatest differences observed in blood tests in children with simple febrile seizure $(\mathrm{AOR}=24.44,95 \% \mathrm{CI}=5.49-108.82)$ and testing for respiratory syncytial virus (RSV) in children with bronchiolitis $\quad(\mathrm{AOR}=21.01, \quad 95 \% \quad \mathrm{CI}=12.23-36.10)$. The service with the lowest odds of occurrence in direct care was cervical cancer screening with HPV test, or Papanicolau test (Pap smear) in children $(\mathrm{AOR}=0.07,95 \% \mathrm{CI}=$ 0.05-0.09). Two services showed no statistical difference: ultrasound in children with cryptorchidism $(\mathrm{AOR}=0.68,95 \% \mathrm{CI}=0.44-1.06)$ and neuroimaging in children with simple febrile seizure (AOR $=1.42$, 95\% $\mathrm{CI}=0.37-5.42$ ). All measures of inappropriate antibiotic prescribing practices (measures 13 to 17) were least likely to occur in direct care, with the lowest odds observed in oral antibiotics for tonsillectomy (AOR $=0.14$, 95\% CI $=0.08-0.25$ ).

\section{Discussion}

In this study, 1 in 7 MHS children received at least one of 20 low-value services during fiscal year 2015. Rates of low-value service use differed according to whether care was delivered in direct versus purchased care, with 6 services significantly more likely to be delivered in direct care and 10 services significantly more likely to be delivered in purchased care. A greater difference in antibiotic prescription practices was also observed, with all 5 
Table 2 Use of 20 Low Value Service Measures and Risk Ratios

\begin{tabular}{|c|c|c|c|c|c|c|c|c|}
\hline No. & Service $^{a}$ & Denominator Definition ${ }^{a}$ & $\begin{array}{l}\text { No. of } \\
\text { Children in } \\
\text { Denominator }\end{array}$ & $\begin{array}{l}\text { No. Receiving } \\
\text { Service at Least } \\
\text { Once During FY }\end{array}$ & $\begin{array}{l}\text { \% of Denom } \\
\text { Receiving } \\
\text { Service at } \\
\text { Least Once } \\
\text { During FY }\end{array}$ & $\begin{array}{l}\text { \% of All } \\
\text { Children } \\
(n=1,111,543) \\
\text { Receiving } \\
\text { Service at } \\
\text { Least Once } \\
\text { During FY }\end{array}$ & $\begin{array}{l}\text { No. of } \\
\text { Services } \\
\text { During FY }\end{array}$ & $\begin{array}{l}\text { No. of } \\
\text { Services } \\
\text { per } 100 \\
\text { Children in } \\
\text { Denominator }\end{array}$ \\
\hline 1 & $\begin{array}{l}\text { Population-based } \\
\text { screening for } \\
\text { vitamin D deficiency }\end{array}$ & All children & $1,111,534$ & 10,242 & 0.92 & 0.92 & 10,753 & 0.97 \\
\hline 2 & $\begin{array}{l}\text { Skin prick test or lgE } \\
\text { blood tests in children } \\
\text { with atopic dermatitis }\end{array}$ & $\begin{array}{l}\text { Children with a } \\
\text { diagnosis of atopic } \\
\text { dermatitis during } \\
\text { the FY }\end{array}$ & 27,659 & 340 & 1.23 & 0.03 & 356 & 1.29 \\
\hline 3 & $\begin{array}{l}\text { Testing for RSV in } \\
\text { children with } \\
\text { bronchiolitis }\end{array}$ & $\begin{array}{l}\text { Children with diagnosis } \\
\text { of bronchiolitis during FY }\end{array}$ & 13,813 & 1096 & 7.93 & 0.10 & 1143 & 8.27 \\
\hline 4 & $\begin{array}{l}\text { Blood tests in } \\
\text { children with a } \\
\text { simple febrile } \\
\text { seizure }\end{array}$ & $\begin{array}{l}\text { Children with diagnosis } \\
\text { of simple febrile seizure } \\
\text { during FY }\end{array}$ & 1987 & 129 & 6.49 & 0.01 & 137 & 6.89 \\
\hline 5 & $\begin{array}{l}\text { Cervical cancer } \\
\text { screening w/ HPV } \\
\text { test or papanicolaou } \\
\text { test in children }\end{array}$ & $\begin{array}{l}\text { Female children aged } \\
\geq 14 \text { years }\end{array}$ & 139,425 & 1115 & 0.80 & 0.10 & 1137 & 0.82 \\
\hline 6 & $\begin{array}{l}\text { Testing for group A } \\
\text { streptococcal } \\
\text { pharyngitis in children } \\
\text { aged }<3 \text { years }\end{array}$ & Children aged $<3$ years & 177,669 & 19,467 & 10.96 & 1.75 & 24,979 & 14.06 \\
\hline 7 & $\begin{array}{l}\text { Face or nose radiograph } \\
\text { in children with head } \\
\text { or face trauma }\end{array}$ & $\begin{array}{l}\text { Children with diagnosis } \\
\text { of head or face trauma } \\
\text { during FY }\end{array}$ & 57,943 & 1013 & 1.75 & 0.09 & 1023 & 1.77 \\
\hline 8 & $\begin{array}{l}\text { Ultrasound in children } \\
\text { with cryptorchidism }\end{array}$ & $\begin{array}{l}\text { Children with diagnosis of } \\
\text { cryptorchidism during FY }\end{array}$ & 1823 & 348 & 19.09 & 0.03 & 354 & 19.42 \\
\hline 9 & $\begin{array}{l}\text { Sinus imaging in } \\
\text { children with acute } \\
\text { sinusitis }\end{array}$ & $\begin{array}{l}\text { Children with diagnosis of } \\
\text { acute sinusitis during FY }\end{array}$ & 44,399 & 68 & 0.15 & 0.01 & 85 & 0.19 \\
\hline 10 & $\begin{array}{l}\text { Neuroimaging in } \\
\text { children with a simple } \\
\text { febrile seizure }\end{array}$ & $\begin{array}{l}\text { Children with a diagnosis } \\
\text { of simple febrile seizure } \\
\text { during the FY }\end{array}$ & 1987 & 39 & 1.96 & 0.00 & 39 & 1.96 \\
\hline 11 & $\begin{array}{l}\text { Neuroimaging in } \\
\text { children with headache }\end{array}$ & $\begin{array}{l}\text { Children aged } \geq 12 \text { years } \\
\text { with a diagnosis of } \\
\text { headache during the } F Y\end{array}$ & 29,801 & 2807 & 9.42 & 0.25 & 3022 & 10.14 \\
\hline 12 & $\begin{array}{l}\text { Cough and cold } \\
\text { medications in } \\
\text { children aged }<6 \text { y }\end{array}$ & Children aged $<6$ years & 363,376 & 108,574 & 29.88 & 9.77 & 136,381 & 37.53 \\
\hline 13 & $\begin{array}{l}\text { Oral antibiotics for } \\
\text { acute upper } \\
\text { respiratory infections }\end{array}$ & $\begin{array}{l}\text { Children with a diagnosis } \\
\text { of acute upper respiratory } \\
\text { infection during the FY }\end{array}$ & 224,222 & 28,156 & 12.56 & 2.53 & 29,440 & 13.13 \\
\hline 14 & $\begin{array}{l}\text { Oral antibiotics for } \\
\text { acute OME }\end{array}$ & $\begin{array}{l}\text { Children with a diagnosis } \\
\text { of acute OME during } \\
\text { the FY }\end{array}$ & 26,313 & 10,553 & 40.11 & 0.95 & 10,872 & 41.32 \\
\hline 15 & $\begin{array}{l}\text { Oral antibiotics for } \\
\text { acute otitis externa }\end{array}$ & $\begin{array}{l}\text { Children with a diagnosis } \\
\text { of acute otitis externa } \\
\text { during the FY }\end{array}$ & 22,399 & 2184 & 9.75 & 0.20 & 2249 & 10.04 \\
\hline 16 & $\begin{array}{l}\text { Oral antibiotics after } \\
\text { tonsillectomy }\end{array}$ & $\begin{array}{l}\text { Children undergoing } \\
\text { tonsillectomy during } \\
\text { the FY }\end{array}$ & 6727 & 612 & 9.10 & 0.06 & 612 & 9.10 \\
\hline 17 & $\begin{array}{l}\text { Oral antibiotics for } \\
\text { bronchiolitis }\end{array}$ & $\begin{array}{l}\text { Children with a } \\
\text { diagnosis of bronchiolitis }\end{array}$ & 13,813 & 2245 & 16.25 & 0.20 & 2368 & 17.14 \\
\hline
\end{tabular}


Table 2 Use of 20 Low Value Service Measures and Risk Ratios (Continued)

\begin{tabular}{|c|c|c|c|c|c|c|c|c|}
\hline No. & Service $^{a}$ & Denominator Definition ${ }^{a}$ & $\begin{array}{l}\text { No. of } \\
\text { Children in } \\
\text { Denominator }\end{array}$ & $\begin{array}{l}\text { No. Receiving } \\
\text { Service at Least } \\
\text { Once During FY }\end{array}$ & $\begin{array}{l}\text { \% of Denom } \\
\text { Receiving } \\
\text { Service at } \\
\text { Least Once } \\
\text { During FY }\end{array}$ & $\begin{array}{l}\% \text { of All } \\
\text { Children } \\
(n=1,111,543) \\
\text { Receiving } \\
\text { Service at } \\
\text { Least Once } \\
\text { During FY }\end{array}$ & $\begin{array}{l}\text { No. of } \\
\text { Services } \\
\text { During FY }\end{array}$ & $\begin{array}{l}\text { No. of } \\
\text { Services } \\
\text { per } 100 \\
\text { Children in } \\
\text { Denominator }\end{array}$ \\
\hline & & during the FY & & & & & & \\
\hline 18 & $\begin{array}{l}\text { Oral corticosteroids } \\
\text { for bronchiolitis }\end{array}$ & $\begin{array}{l}\text { Children with a } \\
\text { diagnosis of bronchiolitis } \\
\text { during the FY }\end{array}$ & 13,813 & 2857 & 20.68 & 0.26 & 3222 & 23.33 \\
\hline 19 & $\begin{array}{l}\text { Short-acting } \beta \text {-agonists } \\
\text { for bronchiolitis }\end{array}$ & $\begin{array}{l}\text { Children with a } \\
\text { diagnosis of bronchiolitis } \\
\text { during the FY }\end{array}$ & 13,813 & 5209 & 37.71 & 0.47 & 5634 & 40.79 \\
\hline 20 & $\begin{array}{l}\text { Acid blockers for infants } \\
\text { with uncomplicated } \\
\text { gastroesophageal reflux }\end{array}$ & Infants aged $<1$ year & 54,023 & 2395 & 4.43 & 0.22 & 5168 & 9.57 \\
\hline
\end{tabular}

${ }^{\mathrm{a}}$ Measures and denominator definitions as described by Chua, et al [11]

services more likely to be received in purchased versus direct care.

The MHS, due to its bifurcated structure, enables a comparison of the provision of care under different payment models, and is especially relevant to discussions of the MHS transition to a high-reliability organization focused on value-based care. Simultaneously, the MHS is planning to reduce the numbers of its uniformed providers, including those providing pediatric care, by 17 , 000 positions in order to fulfill priorities focused on military readiness [12]. Such changes would shift the vast majority of pediatric services for TRICARE beneficiaries to purchased care. In this context, the discussion of low-value pediatric care is both timely and relevant, as it provides an opportunity to reduce costly care that provides no benefit, reduce harm to patients, and repurpose existing resources for more efficient and appropriate use of care. Therefore, this study informs discussion by identifying opportunities to improve pediatric care across the MHS, and evaluating differences in low-value pediatric care between the DC and PC environments.

We found that six low-value procedures are significantly more likely to be provided in direct care: skin prick or IgE blood test for atopic dermatitis, testing for RSV in children with bronchiolitis, blood tests for simple febrile seizure, face or nose radiograph for children with head or face trauma, sinus imaging in children with acute sinusitis, and short-acting beta-antagonists for bronchiolitis. The prevalence of face or nose radiographs after trauma may reflect current military focus on preventing traumatic brain injury, which originates from practice management implications in the adult population. One set of procedures, performing HPV test or Pap smear on children, was much less likely to be performed in direct vs. purchased care. The lower rate in direct care may be the result of outsourcing of care to civilian facilities rather than an overt focus on providing fewer of these procedures across the MHS.

Further insight is gained from comparing rates in the MHS to those seen in private insurance systems. Chua, et al. [11] reported that $9.6 \%$ of children received at least one low-value procedure during 2014. In contrast, $15.4 \%$ of children in the MHS received at least one low-value procedure during 2015. A followup study by Chua, et al. [21] found 1 in 9 publicly insured and 1 in 11 privately insured children receiving LVC in 2014, concurring with earlier findings and demonstrating relatively little difference between their two payment systems.

Significant differences in the rates of two services involving the prescription of oral antibiotics were observed in the MHS compared to publicly and privately insured children. In this study, $9.8 \%$ of the eligible population of military children received oral antibiotics for acute otitis externa, and $9.1 \%$ received oral antibiotics after tonsillectomy. These rates are significantly lower than those found by Chua, et al. (2020) in publicly and privately insured children, with $25.3 \%$ of publicly insured and $24.3 \%$ of privately insured children receiving oral antibiotics for acute otitis externa, and $29.0 \%$ of publicly insured and $27.5 \%$ of privately insured children receiving oral antibiotics after tonsillectomy.

Another notable difference was found in the prescription of cough and cold medicines. In this study, 30\% of the eligible population of military children received one or more cough or cold medicines during the study period, in contrast to the previously-reported $8.5 \%$ of publicly insured and $3.2 \%$ of privately insured children $[11,20]$. A review of coding indicates that this is a true difference and not due to different definitions of these medications between studies. Although the reason for this difference cannot be determined from the data set, 
Table 3 Comparison of Low-Value Care in Direct versus Purchased Care

\begin{tabular}{|c|c|c|c|c|c|c|c|c|}
\hline No. & Service $^{a}$ & $\begin{array}{l}\text { No. } \\
\text { Receiving } \\
\text { Service in } \\
\text { DC }\end{array}$ & $\begin{array}{l}\text { No. } \\
\text { Receiving } \\
\text { Service in } \\
\text { PC }\end{array}$ & $\begin{array}{l}\text { No. in DC } \\
\text { Denominator }\end{array}$ & $\begin{array}{l}\text { No. in PC } \\
\text { Denominator }\end{array}$ & $\begin{array}{l}\% \text { of DC } \\
\text { in the } \\
\text { Denominator } \\
\text { Receiving } \\
\text { Service }\end{array}$ & $\begin{array}{l}\% \text { of } \mathrm{PC} \text { in the } \\
\text { Denominator } \\
\text { Receiving Service }\end{array}$ & $\begin{array}{l}\text { Adjusted }^{\mathrm{b}} \text { OR } \\
(95 \% \mathrm{Cl}) \text { for } \\
\text { Direct Care }\end{array}$ \\
\hline 1 & $\begin{array}{l}\text { Population-based } \\
\text { screening for } \\
\text { vitamin D deficiency }\end{array}$ & 1605 & 3189 & 386,450 & 306,462 & 0.42 & 1.04 & $0.48(0.45-0.51)^{*}$ \\
\hline 2 & $\begin{array}{l}\text { Skin prick test or lgE } \\
\text { blood tests in children } \\
\text { with atopic dermatitis }\end{array}$ & 88 & 29 & 136 & 6975 & 64.71 & 0.42 & $3.23(2.10-4.97)^{*}$ \\
\hline 3 & $\begin{array}{l}\text { Testing for RSV in } \\
\text { children with } \\
\text { bronchiolitis }\end{array}$ & 331 & 25 & 1876 & 2998 & 17.64 & 0.83 & $21.60(14.29-32.65)^{*}$ \\
\hline 4 & $\begin{array}{l}\text { Blood tests in } \\
\text { children with a } \\
\text { simple febrile } \\
\text { seizure }\end{array}$ & 22 & 2 & 180 & 326 & 12.22 & 0.61 & $24.44(5.49-108.82)^{*}$ \\
\hline 5 & $\begin{array}{l}\text { Cervical cancer } \\
\text { screening W/ HPV } \\
\text { test or Papanicolaou } \\
\text { test in children }\end{array}$ & 39 & 721 & 39,269 & 48,531 & 0.10 & 1.49 & $0.07(0.05-0.09)^{*}$ \\
\hline 6 & $\begin{array}{l}\text { Testing for } \\
\text { group A } \\
\text { streptococcal } \\
\text { pharyngitis in } \\
\text { children aged } \\
<3 \text { years }\end{array}$ & 3772 & 4241 & 65,830 & 29,065 & 5.73 & 14.59 & $0.36(0.34-0.38)^{*}$ \\
\hline 7 & $\begin{array}{l}\text { Face or nose } \\
\text { radiograph in } \\
\text { children with } \\
\text { head or face } \\
\text { trauma }\end{array}$ & 207 & 219 & 8892 & 13,910 & 2.33 & 1.57 & $1.98(1.62-2.42)^{*}$ \\
\hline 8 & $\begin{array}{l}\text { Ultrasound in } \\
\text { children with } \\
\text { cryptorchidism }\end{array}$ & 45 & 63 & 282 & 310 & 15.96 & 20.32 & $0.68(0.44-1.06)$ \\
\hline 9 & $\begin{array}{l}\text { Sinus imaging in } \\
\text { children with acute } \\
\text { sinusitis }\end{array}$ & 12 & 40 & 3480 & 20,976 & 0.34 & 0.19 & $1.99(1.03-3.81)^{*}$ \\
\hline 10 & $\begin{array}{l}\text { Neuroimaging in } \\
\text { children with a } \\
\text { simple febrile } \\
\text { seizure }\end{array}$ & 4 & 5 & 180 & 326 & 2.22 & 1.53 & $1.42(0.37-5.42)$ \\
\hline 11 & $\begin{array}{l}\text { Neuroimaging in } \\
\text { children with } \\
\text { headache }\end{array}$ & 175 & 997 & 3084 & 10,632 & 5.67 & 9.38 & $0.59(0.50-0.69)^{*}$ \\
\hline 12 & $\begin{array}{l}\text { Cough and cold } \\
\text { medications in } \\
\text { children aged }<6 \text { y }\end{array}$ & - & - & - & - & - & - & - \\
\hline 13 & $\begin{array}{l}\text { Oral antibiotics for } \\
\text { acute upper } \\
\text { respiratory infections }\end{array}$ & 3235 & 9830 & 50,148 & 54,391 & 6.45 & 18.07 & $0.35(0.34-0.37)^{*}$ \\
\hline 14 & $\begin{array}{l}\text { Oral antibiotics for } \\
\text { acute OME }\end{array}$ & 1219 & 3475 & 3300 & 8419 & 36.94 & 41.28 & $0.82(0.75-0.89)^{*}$ \\
\hline 15 & $\begin{array}{l}\text { Oral antibiotics for } \\
\text { acute otitis externa }\end{array}$ & 333 & 589 & 4069 & 6092 & 8.18 & 9.67 & $0.82(0.72-0.95)^{*}$ \\
\hline 16 & $\begin{array}{l}\text { Oral antibiotics after } \\
\text { tonsillectomy }\end{array}$ & 13 & 211 & 677 & 1815 & 1.92 & 11.63 & $0.14(0.08-0.25)^{*}$ \\
\hline 17 & Oral antibiotics for & 186 & 648 & 1876 & 2998 & 9.91 & 21.61 & $0.48(0.40-0.58)^{*}$ \\
\hline
\end{tabular}


Table 3 Comparison of Low-Value Care in Direct versus Purchased Care (Continued)

\begin{tabular}{|c|c|c|c|c|c|c|c|c|}
\hline No. & Service $^{a}$ & $\begin{array}{l}\text { No. } \\
\text { Receiving } \\
\text { Service in } \\
\text { DC }\end{array}$ & $\begin{array}{l}\text { No. } \\
\text { Receiving } \\
\text { Service in } \\
\text { PC }\end{array}$ & $\begin{array}{l}\text { No. in } \mathrm{DC} \\
\text { Denominator }\end{array}$ & $\begin{array}{l}\text { No. in PC } \\
\text { Denominator }\end{array}$ & $\begin{array}{l}\% \text { of DC } \\
\text { in the } \\
\text { Denominator } \\
\text { Receiving } \\
\text { Service }\end{array}$ & $\begin{array}{l}\% \text { of } P C \text { in the } \\
\text { Denominator } \\
\text { Receiving Service }\end{array}$ & $\begin{array}{l}\text { Adjusted }^{\mathrm{b}} \text { OR } \\
(95 \% \mathrm{Cl}) \text { for } \\
\text { Direct Care }\end{array}$ \\
\hline 18 & $\begin{array}{l}\text { Oral corticosteroids } \\
\text { for bronchiolitis }\end{array}$ & 276 & 684 & 1876 & 2998 & 14.71 & 22.82 & $0.62(0.53-0.72)^{*}$ \\
\hline 19 & $\begin{array}{l}\text { Short-acting } \beta \text { - } \\
\text { agonists for } \\
\text { bronchiolitis }\end{array}$ & 795 & 1158 & 1876 & 2998 & 42.38 & 38.63 & $1.16(1.03-1.31)^{*}$ \\
\hline 20 & $\begin{array}{l}\text { Acid blockers for } \\
\text { infants with } \\
\text { uncomplicated } \\
\text { gastroesophageal } \\
\text { reflux }\end{array}$ & - & - & - & - & - & - & - \\
\hline
\end{tabular}

${ }^{a}$ Measures and denominator definitions as described by Chua, et al [11]

${ }^{b}$ Logistic regression models for each measure were adjusted by age and gender

*Statistically significant Adjusted Odds Ratio (AOR) and 95\% Confidence Interval (CI), p-value $<0.05$

- Data unavailable due to inability to compare direct vs purchased care under defined measure constructs

it may be due to the availability of these medications in the MHS formulary, in which they can be obtained at no cost to the patient when obtained at a Military Treatment Facility or at a very low co-payment at a networked pharmacy, vs. other systems in which the patient bears some cost in obtaining them from a pharmacy or as an over-the-counter product.

A notable finding is the difference in antibiotic prescription patterns between purchased and direct care. In all five cases, children in the direct care system were less likely to receive low-value antibiotic prescriptions (oral antibiotics for acute upper respiratory infection, for otitis media with effusion, for otitis externa, for bronchiolitis, and after tonsillectomy) than in the purchased care system. This is a particular concern in light of current discussions of antibiotic-resistant disease driven in part by inappropriate prescribing practices, although data did not illustrate the reason for the difference between the two care systems.

\section{Strengths and limitations}

There are several notable strengths in this investigation. The population is comprised of a large number of children and adolescents $(n=1,111,534)$ who receive care through universal insurance, and as such, may provide a model for practice patterns in the setting of insurance expansion in the greater US population. Additionally, the provision of care through different practice environment presents opportunities to examine the effect of fixed-fee (direct care) or feefor-service (purchased care) payment models on the delivery of low-value care. Notably for this study, it appears that low-value pediatric care is provided with variation between the fixed-fee vs. fee-for-service system, with greater use of low-value antibiotic treatment taking place in the purchased care sector. This is in similar to previous studies in the MHS adult population which showed utilization of lessinvasive procedures, and greater adherence to treatment guidelines, in direct care $[10,16,21,22]$. Our current findings suggest that current plans to shift pediatric health services in the MHS to purchased care may result in an increase in the use of some low value services while increasing the inappropriate use of antibiotics.

We also recognize several limitations in this work. First, the use of administrative data renders it susceptible to any errors in coding at the provider level, and does not capture the nuances of care in which use of low value procedures may be clinically appropriate. Second, given the use of de-identified data, this study does not have full date of birth for its patients, so that tests provided to children in the first year of life may not be accurately captured.

\section{Conclusions}

Using 20 previously developed measures, this study found evidence of low-value care in pediatric health services in the MHS. Significant differences existed between the provision of low value services in direct and purchased care settings, as well as between the MHS and previous research relying on patients with private insurance. Further research is needed to understand the etiologies behind these differences. In the current period of MHS reform, as pediatric health services are increasingly shifted to the purchased care, the results of our work indicate that such policies may result in increases in low value care and associated expenditures including an increased risk of inappropriate antibiotic use. 


\section{Supplementary information}

Supplementary information accompanies this paper at https://doi.org/10. 1186/s12913-020-05640-5.

Additional file 1. Drugs Used in Measure Definitions. Names and codes of drugs used for investigation of Measures 13-20. Separately uploaded in accordance with Journal guidelines.

\section{Abbreviations}

AHFS: American Hospital Formulary Service; AOR: Adjusted Odds Ratio; Cl: Confidence Interval; DC: Direct Care; DEERS: Defense Enrollment Eligibility Reporting System; Denom: Denominator; DoD: Department of Defense; HPV: Human Papillomavirus; LVC: Low Value Care; MDR: Military Health System Data Repository; MHS: Military Health System; NA: Not Applicable; Num: Numerator; PC: Purchased Care; RSV: Respiratory Syncytial Virus; US: United States; VA: Veterans Affairs

\section{Acknowledgements}

We acknowledge the work of Dr. Kao-Ping Chua and team, whose tool describing 20 measures of low-value pediatric care we adapted in full, and which are reported here exactly as written. No license was required in order to use this tool.

\section{Authors' contributions}

TK, AS, and JW designed the study. TK and $A B$ acquired the data. AB performed the coding and analysis. $A B$ and TK analyzed the data. $Q L, C M$, $A B, T K$, and $A S$ wrote the first draft. CM, AS, JW, and TK provided scientific oversight and critical revision. All authors contributed to data interpretation and approved the final version for publication.

\section{Funding}

This study was funded through the Comparative Effectiveness and ProviderInduced Demand Collaboration (EPIC) / Low-Value Care in the National Capital Region Project, by the United States Defense Health Agency, Grant \# HU0001-11-1-0023. The funding agency played no role in the design, analysis, or interpretation of findings. The contents, views or opinions expressed in this presentation are those of the author(s) and do not necessarily reflect official policy or position of Uniformed Services University of the Health Sciences, the Department of Defense, or Departments of the Army, Navy, or Air Force, or the Henry M. Jackson Foundation for the Advancement of Military Medicine, Inc. Mention of trade names, commercial products, or organizations does not imply endorsement by the U.S. Government.

\section{Availability of data and materials}

The data that support the findings of this study are available from the United States Defense Health Agency. Restrictions apply to the availability of these data, which were used under federal Data User Agreements for the current study, and so are not publicly available.

\section{Ethics approval and consent to participate}

Due the secondary analysis of existing, de-identified data, this study was deemed exempt from human subjects review by the Institutional Review Board of the Uniformed Services University of the Health Sciences. Because of these conditions, written consent to participate, including by parents or guardians for children under 18 , is not applicable. Permission and conditions for use of these data were granted by the United States Defense Health Agency.

\section{Consent for publication}

Due to the secondary analysis of de-identified data, consent for publication is not applicable.

\section{Competing interests}

The authors declare that we have no competing interests.

\section{Author details}

'Uniformed Services University of the Health Sciences, 4301 Jones Bridge Road, Bethesda, MD 20814, USA. ${ }^{2}$ Henry M. Jackson Foundation for the Advancement of Military Medicine, 6720A Rockledge Drive, Bethesda, MD
20817, USA. ${ }^{3}$ Center for Surgery and Public Health, Harvard Medical School, 1620 Tremont Street, Boston, MA 02120, USA.

Received: 6 January 2020 Accepted: 10 August 2020

Published online: 20 August 2020

\section{References}

1. Dieleman, et al. US spending on personal health care and public health, 1996-2013. JAMA. 2016;316(24):2627-46. https://doi.org/10.1001/jama.2016. 16885.

2. Centers for Medicare \& Medicaid Services. National health expenditure data: historical. https://www.cms.gov/research-statistics-data-and-systems/ statistics-trends-and-reports/nationalhealthexpenddata/ nationalhealthaccountshistorical.html. Accessed 13 July 2018.

3. Organization for Economic Co-operation and Development. OECD Health Statistics 2018 - Frequently Requested Data. OECD; 2018. http://www.oecd. org/els/health-systems/OECD-Health-Statistics-2018-Frequently-RequestedData.xIs. Accessed 28 Feb 2019

4. Berwick DM, Hackbarth AD. Eliminating waste in US health care. JAMA. 2012;307(14):1513. https://doi.org/10.1001/jama.2012.362.

5. Morgan DJ, Brownlee $\mathrm{S}$, Leppin $\mathrm{AL}$, et al. Setting a research agenda for medical overuse. BMJ. 2015;351. https://doi.org/10.1136/bmj.h4534.

6. Chan KS, Chang E, Nassery N, Chang H-Y, Segal JB. The state of overuse measurement: a critical review. Med Care Res Rev. 2013;70(5):473-96. https://doi.org/10.1177/1077558713492202.

7. American Board of Internal Medicine. Choosing Wisely | Promoting conversations between providers and patients 2016. Retrieved February 14, 2016, from http://www.choosingwisely.org/.

8. Schwartz AL, Landon BE, Elshaug AG, Chernew ME, McWilliams JM. Measuring low-value care in Medicare. JAMA Intern Med. 2014;174(7):106776.

9. Segal JB, Bridges JFP, Chang HY, et al. Identifying possible indicators of systematic overuse of health care procedures with claims data. Med Care. 2014;52(2):157-63. https://doi.org/10.1097/MLR.0000000000000052.

10. Koehlmoos T, Koehlmoos T, Madsen C, Banaag A, Haider A, Schoenfeld A, Weissman J. Assessing low-value health services in the military health system. Health Aff. 2019;38(8):1351-7.

11. Chua K, Schwartz AL, Volerman A, et al. Use of low-value pediatric services among the commercially insured. Pediatrics. 2016;138(6):e20161809.

12. Office of the Undersecretary of Defense for Personnel and Readiness. Report to the Congressional Defense Committees. "Restructuring and Realignment of Military Medical Treatment Facilities." Pub. L. No 114-328. 19 February, 2020.

13. Zogg CK, Jiang W, Chaudhary MA, Scott JW, Shah AA, Lipsitz SR, Weissman JS, Cooper Z, Salim A, Nitzschke SL, Nguyen LL, Helmchen LA, Kimsey L, Olaiya ST, Learn PA, Haider AH. Racial disparities in emergency general surgery: do differences in outcomes persist among universally insured military patients? J Trauma Acute Care Surg. 2016;80(5):764-77. https://doi. org/10.1097/TA.0000000000001004

14. Schoenfeld AJ, Makanji H, Jiang W, Koehlmoos T, Bono CM, Haider AH. Is there variation in procedural utilization for lumbar spine disorders between a fee-for-service and salaried healthcare system? Clin Orthop Relat Res. 2017;475:2838-44. https://doi.org/10.1007/s11999-017-5229-5.

15. Schoenfeld AJ, Jiang W, Harris MB, et al. Association between race and postoperative outcomes in a universally insured population versus patients in the state of California. Ann Surg. 2017;266(2):267-73. https://doi.org/10. 1097/SLA.0000000000001958

16. Schoenfeld AJ, Kaji AH, Haider AH. Practical guide to surgical data sets: military health system Tricare encounter data. JAMA Surg. 2018;153(7):67980. https://doi.org/10.1001/jamasurg.2018.0480.

17. Chaudhary MA, Leow JJ, Mossanen M, Chowdhury R, Jiang W, Learn PA, Weissman JS, Chang SL. Patient driven care in the management of prostate cancer: analysis of the United States military healthcare system. BMC Urol. 2017;17(1):56

18. Ranjit A, Jiang W, Zhan T, Kimsey L, Staat B, Witkop $C T$, Little SE, Haider AH, Robinson JN. Intrapartum obstetric care in the U.S. Military: Comparison of military and civilian systems within TRICARE. Birth. 2017. https://doi.org/10. 1111/birt.12298

19. Madenci $A L$, Armstrong $L B$, Kwon N, Jiang W, Wolf $L L$, Koehlmoos TP, Ricca RL, Weldon CB, Haider AH, Weil BR. Incidence and risk factors for sepsis after 
childhood splenectomy. J Pediatr Surg. 2018. https://doi.org/10.1016/j. jpedsurg.2018.06.024 [Epub ahead of print].

20. Chua K-P, Schwartz AL, Volerman A, Conti RM, Huang ES. Differences in the receipt of low-value services between publicly and privately insured children. Pediatrics. 2020;145(2):e20192325. https://doi.org/10.1542/peds. 2019-2325 Epub 2020 Jan 7.

21. Nguyen LL, Smith AD, Scully RE, Jiang W, Learn PA, Lipsitz SR, Weissman JS, Helmchen LA, Koehlmoos T, Hoburg A, Kimsey LG. Provider-induced demand in the treatment of carotid artery stenosis: variation in treatment decisions between private sector fee-for-service vs salary-based military physicians. JAMA Surg. 2017;152(6):565-72

22. Dietrich E, Santiago C, Leroux T, Helgeson M, Richard P, Koehlmoos T. Assessing practice pattern differences in the treatment of acute low back pain in the United States military health system. BMC Health Serv Res. 2018; 18(1):720. https://doi.org/10.1186/s12913-018-3525-8.

\section{Publisher's Note}

Springer Nature remains neutral with regard to jurisdictional claims in published maps and institutional affiliations.

Ready to submit your research? Choose BMC and benefit from:

- fast, convenient online submission

- thorough peer review by experienced researchers in your field

- rapid publication on acceptance

- support for research data, including large and complex data types

- gold Open Access which fosters wider collaboration and increased citations

- maximum visibility for your research: over $100 \mathrm{M}$ website views per year

At BMC, research is always in progress.

Learn more biomedcentral.com/submissions 